\title{
Investigating the Leadership Role of Head of Departments of the Arabic Language on Teaching and Learning: Abu Dhabi Private Schools as a Case Study
}

\author{
Mohamad Ezzat Alkutich \\ British University, Dubai
}

\begin{abstract}
This paper aims to examine the leadership role of the Head of Department (HoD) in teaching and learning of Arabic language in two of Abu Dhabi's private schools. The main research question is what is the impact of the HoD on teaching and learning Arabic language in Abu Dhabi private schools? This piece of research employs a qualitative methodological approach, whereby data were gathered from two private schools in Abu Dhabi. A Pilot study with 3 teachers and one HoD was conducted; 8 semi-structured interviews were employed with two head teachers, 2 HoDs and 4 teachers in two private international schools in Abu Dhabi.
\end{abstract}

The findings of this paper were that no formal preparation was provided to HoDs for leading the teaching and learning of Arabic language, HoDs practise their leadership role by running class observation, monitoring (teaching and learning, lesson plans, students' work and assessment) and providing teachers with feedback. HoDs lack of pedagogical knowledge, lack of curriculum design and implementation. The study found that HoDs face variety of challenges, such as, lack of teaching and learning resources, demotivated teachers, heavy workload and paperwork, HoDs perceived by teachers as fault hunters and lack of leading by example, and lack of quality CPD.

This study provides the following recommendations; HoDs should be provided with courses about the subject and curriculum knowledge and the leadership role. HoDs need to be trained about quality monitoring teachers' work and students learning and how to be critical friends. HoDs should engage Arabic teachers in planning, monitoring and evaluation processes.

\section{INTRODUCTION}

Educational leadership is one of the key aspects of improvement in education worldwide. The literature presents leadership as a significant factor in school success and betterment (Earley \& Weindling, 2004). In the UAE, school management team (SMT) includes school principals, deputy heads and head of departments. This paper focuses on the head of departments (HoDs). The literature is full of research and studies about the impact and role of HoDs, but with a different given name, such as, subject leaders, coordinators, middle leaders and department chair. In this study, I will use the acronym 'HoDs' as it is very common in Abu Dhabi schools. Besides, both schools that I chose for this research use it as well.

\section{PROBLEM STATEMENT OF THE STUDY}

HoDs have lots of tasks to do while leading the teaching and learning. However, majority of HoDs lack significant skills and competences as leaders. In the literature, it is found that HoDs are not ready to lead (Turner, 2000), they learn during doing their job, and lack of time for planning and leading (Ali \& Botha, 2006; Zepeda \& Kruskamp, 2007; Rosenfeld et. al, 2009; Bak, 2010). Almost all the continuous professional development (CPD) that HoDs attended is not relevant to their leadership role (Stephenson, 2010).

\section{THE RATIONALE OF THE STUDY}

The rationale of this research is based on my experience as a teacher and as $\mathrm{HoD}$ who was holding this position as the best of the team (in the viewpoint of the principal), with years of experience and fluency of English language, not based on the leadership experience. I've learnt about the role of HoD from other HoDs who had the same experience of not being prepared for the leadership. To the best of my knowledge, there is a lack of research about the leadership impact of the HoDs in teaching and learning the Arabic language neither in primary or secondary school. The poor performance of the Arabic language among the learners in Abu Dhabi private schools as it is shown in the inspection 
reports (ADEC, 2017) and the lack of research about the role of HoDs in teaching and learning the Arabic language are significant calls for this piece of research.

\section{THE PURPOSE OF THE STUDY}

The aim of this study is to investigate the perceptions of school educators about the leadership role of HoDs in teaching and learning the Arabic language in the private schools of Abu Dhabi, as well as to provide educators with some answers might help in improving the role of Arabic language HoDs.

\section{THE SIGNIFICANCE OF THE STUDY}

Many studies have been carried out exploring the different roles of the HoDs in schools; however, there is a lack of research about the impact of leadership role of HoDs on teaching and learning.

\section{THE RESEARCH QUESTIONS}

This study is based on one key research question and four sub-questions. The main research question is "What are the perceptions of school educators regarding the leadership role of the head of departments HoDs in teaching and learning of the Arabic language?". The sub-questions are;

1- What are the responsibilities of HoDs as subject leaders in teaching and learning of the Arabic language?

2- What are the formal or informal preparatory courses that HoDs provided with while leading teaching and learning of the Arabic language?

3- What are the leadership activities that HoDs practise in leading teaching and learning of the Arabic language?

4- What are the challenges that HoDs face while performing the leadership of teaching and

\section{LITERATURE REVIEW}

Leadership in literature is defined differently. Kruger, in his research depicted that leadership is a mechanism of communicating team members with missions, goals and objective (2003). In another study, Leithwood and Riehl (2003) claimed that leadership is about directions and influence. However, Hoerr (2005:7) pointed that "leadership is about leadership". Yukl (2006) asserted that leadership is the art of attracting staff to achieve a common goal, it is a two way event when leaders and followers affect and affected by each other. In education, there are various approaches of leadership, the main two that are relevant to the purpose of this study are instructional leadership and distributed leadership.

\section{INSTRUCTIONAL LEADERSHIP}

The concept "Instructional leadership" is about the relationship between teachers and learners regarding teaching and learning activities (Bush \& Glover, 2002). Besides, it is about leading teaching and learning (Robinson, 2006; Bush, 2007). As school principals are overall leaders, it is found that principals have no direct influence on teaching and learning, and it is delegated to HoDs (Bush, 2003).

\section{DISTRIBUTED LEADERSHIP}

The concept "distributed eldership" is recent notion in educational literature, and it is described as the practice of school leaders in guiding and influencing the development of teaching and learning (Spillane \& e.t, 2003: P.535). In UK, Hammersley and others (2005) found that where distributed leadership is applied, there will be collaboration between staff for school improvement, also there will be an appreciation of delegation of responsibilities, and knowledge development, innovation and creativity are expected.

\section{STUDIES ON HoDs}

Regarding their roles and responsibilities, a study in UK (Fletcher \& Bell,1999) found that the roles and responsibilities of subject leaders are many. Such as, providing and administrating the resources and making them available; influencing the performance of quality teaching and learning; monitoring and evaluating teachers work according to the set targets and goals; subject knowledge; providing CPD to the teachers in the department based on their needs; supporting teachers by listening to them and communicating with them effectively. However, Fletcher and Bell claimed that HoDs were facing different challenges. Such as, lack of time for development; lack of time for monitoring; and lack of cooperation among the staff.

On other hand, Bennet and others (2003) found in their research that subject leaders were not happy to run classroom observation; lack of subject knowledge compared to some teachers in the department. Ali and Botha (2006) in their study in South Africa found that the role of subject leaders has a significant impact on school improvement. In another study conducted in UK, Poultney (2007) claimed that subject leaders should be approachable and supportive to teachers. Besides, the study found that subject leaders were challenged in delegating duties and responsibilities. 
In Australia, Rosenfeld and others (2009), discovered that HoDs were not aware of the leadership skills, and they lack trainings about middle leadership roles, the participants HoDs in this study claimed that they only learn on the job. Regarding the skills and competences that HoDs should have, a study conducted in Singapore by Heng and Marsh (2009) found that HoDs are required to sharpen their interpersonal skills, have subject knowledge, and pedagogical understanding of their subject. HoDs should be fair and just in their judgement.

\section{HoDs instructional supervision}

HoDs are the instructional leaders of their subjects, and the role of instructional supervision is delegated to them, so they are in charge of the quality of teaching and learning (Bush, 2007). Zepeda and Kruskamp (2007) conducted a study in the USA investigating the perceptions of HoDs about the provision of instructional supervision in their departments. It was found that HoDs were not prepared for the supervision role, they also lack support and guidance from the principals, and they faced role ambiguity in their assigned position, and role tension.

\section{HoDs PREPARATION FOR LEADERSHIP}

The literature shows that the position of head of department is given to teachers based on their years of experience and how perfect they appear in the interview as a way of marketing themselves (Turner, 2000). In his study, Turner (2000) found that HoDs learn from other HoDs with more experience, and they treat them as their role models, they also learn from leadership and management workshops.

\section{Skills and competences of HoDs}

In order to perform better leadership role, HoDs needs to have particular competences and skills to fulfil their responsibilities of the quality of teaching and learning. Bak (2010) in her study depicted that HoDs need to improve their interpersonal skills, administration work, subject knowledge, curriculum design and development, supervision and evaluation and continuous professional development. Stephenson (2010) illustrated the skills and competences that HoDs should have as leaders. Such as; subject knowledge; assessment knowledge; pedagogical knowledge; shared vision; strategic planning; team development; providing relevant CPD; people management; communication skills; time management; and delegation skills.

\section{Challenges of HoDs}

Head of departments face various issues in leading teaching and learning. Stephenson (2010) found that there are many challenging facing HoDs, such as, time workload, leadership knowledge, lack of CPD directed at HoDs to assist them.

\section{Research Methodology}

\section{Methodological approach}

This study investigates the perceptions of school educators about the leadership role and impact of HoDs on teaching and learning the Arabic language in international schools in Abu Dhabi. A qualitative approach was employed in order to gather the perspectives of the participants. This qualitative approach allows the researcher to hear the voice of participants and gives him a deep understanding of their point of views (Yin, 2011:P.8). Qualitative methodology provides the researcher with better understanding of the phenomenon (Creswell, 2012).

\section{Research Sample}

This research is a case study of two international schools in Abu Dhabi, based on the curriculum provided by each school and based on the inspection report in Arabic language conducted by Abu Dhabi Educational council ADEC in the academic year 2016-2017, both schools have very good inspection grade with a good performance in Arabic language. These nominated schools are one follow the British curriculum and one follows the American curriculum, and both of them are secondary schools.

A Pilot study was conducted with one head of department and 3 teachers to assure the time needed to the interview and clarity of the questions.

\section{Participants}

The participants were 8 school educators from both schools, from each school there was one head teacher, one Arabic language head of department and two teachers of Arabic language. An email was sent to 7 schools that fit my criteria to ask permission to conduct this study, however only 3 schools replied positively. The teachers were one teacher for native speakers and one for non-native speakers from each school. Demographically, it was meant to have a balance percentage 50\% among the participants' males and females, however, participants were 2 males head teachers, one male and one female HoDs, and three female teachers and one male teacher.

\section{Data Collection}

Prior to the study, I sent an email to the head teachers of the participant schools to get their permission to conduct this study, another email was sent as well to the participants as an invitation to partake in this research, attached with the 
email a form of ethical clearance was sent as well to be signed by the partakers.

\section{Semi-Structured interview}

Semi-Structured interview was employed as the main qualitative tool to collect the data of this study. The significance of this tool that it is helpful to extract data from personnel opinions and beliefs and the shortcomings of such a tool are the unwillingness of the participants to reveal their experiences and the potential bias or unreliability.

\section{Data Analysis}

In this stage of the research, data analysis refers to the interpretation of the collected data, to make sense from the perceptions of the participants (Jansen \& Vithal, 2001). To the sake of the best data analysis result, the researcher used content analysis method to get a useful briefing of the collected data, and content analysis method enables the researcher to code, categorise and compare data and it shapes the theoretical conclusion (Cohen et. al., 2011).

\section{The Credibility of the Study}

In order to ensure the validity of the findings of this study, I have applied different tools. Such as, triangulation by using different categories of the participants (Creswell, 2012), in this regard, the researcher included three categories of participants, namely, head teachers, head of departments and teachers. Besides, relevant documents to the research questions were retrieved. Finally, a pilot study with one head of department and three Arabic teachers was applied.

\section{Dependability of the Study}

Achieving a high level of dependability in qualitative study can be ensured by different ways. In this regard, the researcher preserved all the notes, records and transcripts of the interviewees. Moreover, participants were treated by the researcher as partner in this research. Finally, with respect to the experiences of the participants and their potential bias, I made certain that the interview questions are relevant to the research questions, and I also did not use any leading questions with the interviewees.

\section{Ethical Considerations of the Study}

Ethical consideration is one of the significant pillars of the qualitative research, thus, both trust and privacy protection need to be guaranteed to make sure that interviewees reveal their own perspective based on their experiences (Creswell, 2012). In this regard, I have sent via email, a consent form to be signed by the participants, I also ensured that all the participations were mere voluntary. Besides, participants were informed that they can withdraw at any time and they have the right not to answer any of the interview questions. Moreover, permission for audio recording was requested.

\section{FINDINGS AND DISCUSION}

The participants in this study come from two international schools in Abu Dhabi of the UAE. One of these schools follow the British curriculum and the second school follows the American curriculum, both of them entitled a very good overall inspection report with acceptable grade for the Arabic language. in these two schools, 8 participants were involved and interviewed in this study, two head teachers, two Arabic language head of departments and four Arabic teachers. As it is shown in (Table 1), both head teachers have more than 17 year teaching experience, and more than 7 years leadership experience, and both of them carry a master degree in education. On other side, bot head of department have more than 10 years teaching experience in Arabic language, one of them has good leadership experience for 7 years. However, the other one is in her first year as a head of department. Both HoDs have a bachelor degree in Arabic but no one hold a master degree. Regarding the Arabic teachers, the majority of participants have more than 10 year teaching experience, $50 \%$ of them has no leadership experience. Besides, $100 \%$ of the teachers participants hold a bachelor degree in Arabic language, and one of them hold master degree. It is clearly shown in Table 1 that in one of these schools these is a teacher who has more leadership experience and educational degree than his head of department, one teacher commented; that there is no clear criteria for successful candidates for the position of head of department,

\begin{tabular}{|l|l|l|l|l|l|l|}
\hline Partic & $\begin{array}{l}\text { Sc } \\
\text { ipant }\end{array}$ & $\begin{array}{l}\text { Tea } \\
\text { chi } \\
\text { ol }\end{array}$ & $\begin{array}{l}\text { Lea } \\
\text { ders } \\
\text { exp } \\
\text { hip } \\
\text { exp } \\
\text { nce } \\
\text { erie } \\
\text { nce } \\
\text { per } \\
\text { yea } \\
\text { year }\end{array}$ & $\begin{array}{l}\text { G } \\
\text { de } \\
\text { r }\end{array}$ & $\begin{array}{l}\text { A } \\
\text { g } \\
\text { e }\end{array}$ & $\begin{array}{l}\text { Quali } \\
\text { ficati } \\
\text { on }\end{array}$ \\
\hline $\begin{array}{l}\text { Head } \\
\text { teach } \\
\text { er }\end{array}$ & A & 20 & 10 & F & $\begin{array}{l}4 \\
7\end{array}$ & $\begin{array}{l}\text { MED } \\
\text { in } \\
\text { Educ } \\
\text { ation }\end{array}$ \\
\hline $\begin{array}{l}\text { Head } \\
\text { teach } \\
\text { er }\end{array}$ & B & 18 & 8 & M & 5 & $\begin{array}{l}\text { MED } \\
\text { in }\end{array}$ \\
\hline
\end{tabular}




\begin{tabular}{|c|c|c|c|c|c|c|}
\hline & & & & & & $\begin{array}{l}\text { Educ } \\
\text { ation }\end{array}$ \\
\hline $\begin{array}{l}\text { Head } \\
\text { of } \\
\text { depar } \\
\text { tment } \\
1\end{array}$ & A & 19 & 7 & $\mathrm{M}$ & 4 & $\begin{array}{l}\text { Bach } \\
\text { elor } \\
\text { degre } \\
\text { e in } \\
\text { Arabi } \\
\text { c }\end{array}$ \\
\hline $\begin{array}{l}\text { Head } \\
\text { of } \\
\text { depar } \\
\text { tment } \\
2\end{array}$ & B & 10 & 1 & $\mathrm{~F}$ & $\begin{array}{l}3 \\
3\end{array}$ & $\begin{array}{l}\text { Post- } \\
\text { Gradu } \\
\text { ation } \\
\text { Diplo } \\
\text { ma \& } \\
\text { Bache } \\
\text { lor } \\
\text { degree } \\
\text { in } \\
\text { Arabi } \\
\text { c }\end{array}$ \\
\hline $\begin{array}{l}\text { Arabi } \\
\text { c } \\
\text { teach } \\
\text { er } 1\end{array}$ & A & 12 & 2 & $\mathrm{~F}$ & $\begin{array}{l}3 \\
5\end{array}$ & $\begin{array}{l}\text { Bache } \\
\text { lor } \\
\text { degree } \\
\text { in } \\
\text { Arabi } \\
\text { c and } \\
\text { Islami } \\
\text { c }\end{array}$ \\
\hline $\begin{array}{l}\text { Arabi } \\
\text { c } \\
\text { teach } \\
\text { er } 2\end{array}$ & $\mathrm{~A}$ & 15 & 0 & $\mathrm{~F}$ & $\begin{array}{l}3 \\
7\end{array}$ & $\begin{array}{l}\text { Post- } \\
\text { Gradu } \\
\text { ation } \\
\text { Diplo } \\
\text { ma \& } \\
\text { Bache } \\
\text { lor } \\
\text { degree } \\
\text { in } \\
\text { Arabi } \\
\text { c }\end{array}$ \\
\hline
\end{tabular}

\begin{tabular}{|l|l|l|l|l|l|l|}
\hline $\begin{array}{l}\text { Arabi } \\
\text { c } \\
\text { teach } \\
\text { er 3 }\end{array}$ & B & 16 & 4 & M & $\begin{array}{l}4 \\
0\end{array}$ & $\begin{array}{l}\text { Maste } \\
\text { r } \\
\text { degree } \\
\text { in } \\
\text { Arabi } \\
\text { c }\end{array}$ \\
\hline $\begin{array}{l}\text { Arabi } \\
\text { c } \\
\text { teach } \\
\text { er 4 }\end{array}$ & B & 4 & 0 & F & $\begin{array}{l}2 \\
8\end{array}$ & $\begin{array}{l}\text { Bache } \\
\text { lor } \\
\text { degree } \\
\text { in } \\
\text { Arabi } \\
\text { c }\end{array}$ \\
\hline
\end{tabular}

Table 1: Demography description of the participants

(Coding School A/B it does not mean that A for American school nor B fo British school).

\section{The Pilot Study}

Interview questions were tested by a pilot study to ensure the clarity of questions and the needed time for the interview process. Kim (2011) highlighted this small-scale methodology was carried out as a preparation to the study, so the researcher adjust his research plan accordingly.

As it was mentioned earlier, that three schools accepted to participate in this study, so out of these schools one was selected to run the pilot study. It was planned to interview the head teacher but she had a busy schedule at that time, so the members of this pilot study were one head of department and three Arabic teachers.

\section{Research Question 1: The Responses of Head} Teachers

Regarding the first research question "What are the responsibilities of HoDs as subject leaders in teaching and learning of the Arabic language?" head teachers responses came into four categories of roles that HoDs play as leaders. Namely;

\section{Administration role}

Head teachers participants in this study believe that the main responsibility of HoDs is administration, as they are in charge of monitoring the register and attendance of both teachers and students in the department. One head teacher said: " Part of being outstanding school, subject leader should record the attendance of teachers to assure that 
teaching is taking place, and to record pupils attendance as well, to give avoidance why particular students (Absentees) are not learning". Besides, they are responsible of providing the needed resources and material for teaching and learning. A head teacher added: "Head of department should be the best who know what resources and books we need to make sure that quality teaching and learning is taking place".

\section{Curriculum Management Role}

As part of HoDs responsibilities, head teachers think that HoDs are the ones guarantee that the curriculum is linear with the national agenda and meets the long term goals of the subject. One head teacher indicated: "Head of department is in charge of curriculum delivery, by choosing in association with teachers what topics to be taught and what learning objectives to be achieved".

\section{Supervision Role}

$\mathrm{HoD}$ as supervisor is another responsibility perceived by head teachers. Supervision role includes monitoring lesson plan, annual plan, assessment and classroom observation. One head teacher said: "head of department needs to check lesson plans, assessment coverage and teaching strategies". Another head teacher highlighted: "As a principal, I have delegated classroom observation to the head of department, this tool is very important for school leaders, to assure that curriculum is delivered as it was planned by skilful teachers so our students enjoy while learning"

\section{Support Role}

Head teachers believe that part of head of department's responsibilities is to provide support to teachers and students. A head teacher pointed: "Subject leader should support teachers by being a critical friend, facilitating their work, giving advices and needed CPDs". Another head teacher said: "When it comes to support, experienced teachers and new teachers need support in different ways from their head of department, also students need support by providing special tasks to those with special needs and the gifted and talented".

\section{Responses of Head of Departments}

Similar to the head teachers, head of department's responses came into the same four categories for the first research question "What are the responsibilities of HoDs as subject leaders in teaching and learning of the Arabic language?" However, HoDs added one more category which is evaluation and appraisal. With respect to these categories, the responses of HoDs were as the following:

\section{Administration Role}

All HoDs participants agreed that the administration role is one of their key responsibilities. This role consist of ordering and providing resources and subject materials, taking notes out of school meetings, approving teachers' print outs, providing cover for absent teachers and dealing with the process of hiring new teachers. One head of department said: "We lack enough teachers in our school, so I have to search for new candidates, call them, meet them, observe their demo lessons, and also to cover or find a cover teacher for the class with no teacher to teach"

\section{Curriculum Management Role}

Managing the curriculum is the second agreed role between head teachers and HoDs. From the point of view of HoDs, curriculum management includes monitoring the process of teaching and learning, teaching strategies and assessment. One head of department commented: "I am responsible to check whether or not teaching and learning of the Arabic language is taking place in all year groups and all teachers, it is my duty to assure that teachers are teaching as we have planned in the beginning of the year". Another head of department said: "Teaching nowadays is really complicated and not all teachers good in it, so my part is to make lesson observation to enhance teachers to engage all students by learner-cantered teaching strategies. Sometimes I visit classroom and see there is teaching, but eventually no learning is achieved!"

\section{Supervision Role}

As part of supervision task, HoDs are responsible to check whether or not teachers adhere to the department plan, scheme of work and curriculum coverage. One head of department pointed: "In my department there are some teachers that are not totally committed to the subject policy, one of them do not check students' work, another one do not give homework frequently, and most of them do not cover teaching all the planned topics of the curriculum" Another head of department added: "All the teachers in the department are not strictly committed to make a written lesson plan and they claim that they have it in their mind and they are experience teachers so they know what to do in the classroom, but I believe that this is wrong and really I do not know how to encourage them to do it. When I force them to do lesson planning, it takes from them more than 1 hour for each lesson, it is too much as they have about 7 daily lessons".

\section{Support Role}

HoDs articulated that it is part of their responsibilities as subject leaders to support teachers with the needed professional development. One head of department said: "Part of the improvement plan of my department is to support those teachers who lack experience and teaching strategies" 


\section{Teacher Appraisal Role}

This point is the only different one comparing to the head teachers above mentioned points. Head of departments believe that they are in charge of evaluating overall teachers' performance.

One head of department stressed: "It is a significant role I have, which is evaluating teachers overall practice, because in my school, the senior leader team the only things that they care about, that the kids have a teacher, and this teacher is good in speaking English. However, they are not aware about the quality of teaching of this teacher".

\section{Teachers Participants Responses}

All teachers agreed that it is the responsibility of head of departments to assist teachers and support them. Unfortunately, all teachers participants as well agreed that their HoDs do not do so. One teacher said: "Our head of department is responsible to provide us with support, but he does not do this, instead he is a fault hunter!". Another teacher has this to say: "I respect my subject leader, she is so kind to us, but she does not that experience to help or support us". Moreover, one teacher claimed: "my head of department is a very hard worker to improve his own skills, but he never ever sent us to any workshop nor he delivered any CPD" On other side, one teacher pointed: "Part of our school culture is to exchange classroom observations and visits across the whole school, but he never invited or allowed us to visit his class to learn from his practice about the things that he does not like in our classes".

\section{Participants' Responses on Research Question 2}

Regarding the second sub-research question "What are the formal or informal preparatory courses that HoDs provided with while leading teaching and learning of the Arabic language?", the perceptions of both categories of participants, head teachers and head of departments were investigated. Head teachers agreed that HoDs in their schools did not have any preparatory course in order to hold their positions. One head teacher said: "I think that the years of experience in teaching and subject knowledge are what they have". Another head teacher added: "yes she does not have any experience in leadership, but we are offering her an opportunity to learn and get the needed experience". Similarly, one head of department said: "I was just a teacher, and I showed my interest in leading the department, I had no leadership experience, I attended lots of workshop, but none was about middle leadership".

\section{Participants' Responses on Research Question 3}

Responding to the third sub-research question "What are the leadership activities that HoDs practise in leading teaching and learning of the Arabic language?", three themes emerged. Such as, monitoring, hiring teachers and resources availability. All the three participant groups of head teachers, HoDs and teachers agreed about monitoring role and disagreed about the other two roles. However, HoDs added that part of their responsibilities is to manage the process of hiring new qualified teachers and providing them with trainings to facilitate their work as new bees in the school. Teachers' participants added that HoDs are in charge about the provision of resources and materials.

One head teacher said: "He has to check lesson plans, students work and curriculum coverage". A HoD added: "There is too much work to do; besides teaching my classes, I have to make sure that teachers planning their lessons and checking learners books; and finding, interviewing and hiring new expert teachers" On other side, one teacher pointed: "The head of department is responsible as a budget holder to make sure that the needed materials, books and resources are available.

\section{Participants' Responses on Research Question 4}

The forth sub-research question was "What are the challenges that HoDs face while performing the leadership of teaching and learning of the Arabic language?" and the responses brought four themes. Such as, workload, leadership, training, support and communication. Both head teachers and HoDs agreed that the workload of HoDs is so tough. One head teacher said: "They are teachers as well and they have to plan and teach their classes, and to deal with the issues of their departments, we try to give them less teaching classes, but when a teacher is absent or left the job , HoD is taking her place.”.

Also both groups were in agreement about the training issue. A head teacher had this to say: "she is not qualified as a leader, but he is an excellent teacher, we gave her the opportunity to learn and get experience, we send her to workshops as well". One HoD added: "I learn how to lead while doing my job, I go to workshops but none is about middle leadership" One teacher said: "Yes he pretend that he is a perfect leader, but he is not good in leadership skills at all, we meet weekly but useless there is no goal, no strategic plan".

Regarding the support and communication, A HoD said: "Some teachers do not do their work as it should be, they are here just for the salary, you ask them to do thing lots of time then they do it", one teacher claimed: "Some times and 
because she does not know how to do things, she deal with teachers in a very bad way, I mean here that asking as to do things without discussing then we do the same thing again differently". Another teacher stressed: "He is not that supportive, most of the time he acts as a fault hunter, not showing respect when talking, I think without him we can do things better, just leave us do our work!!"

\section{Discussion}

In reviewing the responses of the participants of the three groups, one can see that there are some similarities and differences on the viewpoints of the research questions. All the partakers in this research agreed that HoDs are not prepared as leaders, and they lack leadership skills training and courses. All participants as well are in agreement that HoDs are there to support, assist and facilitate teachers work. Head teachers and HoDs articulated that there is no such a professional program or course about middle leadership.

However, head teachers think that being an experienced teacher is adequate to be appointed as a head of department. In other point, teachers believe that HoDs should be skilful in team work and communication as in practice there signs of disrespect, autocracy and fault hunting.

\section{Results and Conclusions}

As a result of the research to answer the key research question "What are the perceptions of school educators regarding the leadership role of the head of departments HoDs in teaching and learning of the Arabic language? " the research found that;

- Head teachers in reality are not aware about the importance of preparing HoDs in middle leadership skills.

- HoDs hold the responsibilities of curriculum management, monitoring and providing support.

- Lack of formal preparation for HoDs about middle leadership.

- HoDs face different challenges; frequent shortcomings in teachers availability, demotivated teachers, workload and paperwork, leadership skills, curriculum knowledge, communication skills.

\section{Recommendations}

- It is recommended that Ministry of Education and ADEC to require schools to give the position of HoD only for those teachers with leadership qualification.

- Ministry of Education and ADEC are recommended to establish a course and approval for HoDs.

- Schools are recommended to hold frequent courses and conferences for HoDs and teachers.

- Head teachers are recommended to support HoDs with leadership trainings.

- Schools and HoDs to involve teachers in decision making and delegation.

- HoDs to communicate effectively with teachers by supporting and facilitating their work and as critical friends, so teachers would not see HoDs as fault hunters.

\section{Limitations and Further Studies}

This study uses a qualitative approach and its sample is just two international schools in Abu Dhabi, so its results and findings can't be generating to other types of schools or even other departments nor to other emirates or countries. I recommend that for future studies to increase the sample and use mixed research methodology to investigate the impact of HoDs of Arabic language on teaching and learning.

\section{REFERENCES}

ADEC, (2017). Inspection Reports, [Retrieved 29-6-2017 from: https://www.adec.ac.ae]

Ali, A.F. \& Botha, N. (2006). The role, importance and effectiveness of Heads of department in contributing to school improvement in public secondary schools in Gauteng. Matthew Goniwe School of Leadership and Governance, Johannesburg.

Bak, S. O. S. (2010). Competencies of secondary school Heads of department; Implications on continuous professional development, European Journal of Social Sciences, 14(3), 464-470.

Bennett, N., Newton, W. Wise, C., Woods, P. A. \& Economou (2003). Research report. 


\section{International Journal of Science and Engineering Applications \\ Volume 6 Issue 09, 2017, ISSN-2319-7560 (Online)}

Bush, T \& Glover, D. (2002). School Leadership: Concepts and Evidence. Nottingham.

Bush, T., 2003. Theories of educational leadership and management. Sage.

Bush, T., 2007. Educational leadership and management: Theory, policy and practice. South African journal of education, 27(3), pp.391-406.

Cohen, L., Manion, L. and Morrison, K., 2011. Surveys, longitudinal, cross-sectional and trend studies. Research Methods in Education, 7th edition. Abingdon: Routledge, pp.261-4.

Creswell, J.W., 2012. Collecting qualitative data. Educational Research: Planning, Conducting, and Evaluating Quantitative and Qualitative Research. Fourth ed. Boston: Pearson, pp.204-35.

Earley, P. and Weindling, D., 2004. Understanding school leadership. Sage.

Fletcher, L. and Bell, D., 1999. Subject leadership in the primary school: Views of subject leaders.

Hoerr, T.R., 2005. The art of school leadership. ASCD.

Hammersley-Fletcher, L. and Brundrett, M., 2005. Leaders on leadership: the impressions of primary school head teachers and subject leaders. School leadership \& management, 25(1), pp.59-75.

Heng, M.A. and Marsh, C.J., 2009. Understanding middle leaders: A closer look at middle leadership in primary schools in Singapore. Educational Studies, 35(5), pp.525536.

Kim, Y., 2011. The pilot study in qualitative inquiry: Identifying issues and learning lessons for culturally competent research. Qualitative Social Work, 10(2), pp.190206.

Kruger, A.G., 2003. Instructional leadership: the impact on the culture of teaching and learning in two effective secondary schools. South African journal of education, 23(3), pp.206-211.

Leithwood, K. and Riehl, C., 2003. What do we already know about successful school leadership? Paper prepared for the AERA Division A Task Force on Developing Research in Educational Leadership.

Jansen, J. and Vithal, R., 2001. Designing your first research proposal: A manual for researchers in education and the social sciences. Lansdowne: Juta \& Co, Ltd.

Poultney, V., 2007. The role of the effective subject leader: Perspectives from practitioners in secondary schools. Management in Education, 21(2), pp.8-14.
Robinson, V.M., 2006. Putting education back into educational leadership. Leading and managing, 12(1), p.62.

Rosenfeld, P., Ehrich, L.C. and Cranston, N., 2009. Changing roles of heads of department: a Queensland case.

Spillane, J.P., Hallett, T. and Diamond, J.B., 2003. Forms of capital and the construction of leadership: Instructional leadership in urban elementary schools. Sociology of Education, pp.1-17.

Stephenson, A., 2010. An examination of the issues facing heads of departments in New Zealand secondary schools (Master's thesis).

Turner, C., 2000. Learning about leading a subject department in secondary schools: Some empirical evidence. School Leadership \& Management, 20(3), pp.299313.

Yin, R.K., 2011. Applications of case study research. Sage. Yukl, G., 2006. \& (2002)" Leadership in Organizations".

Zepeda, S.J. and Kruskamp, B., 2007. High school department chairs-perspectives on instructional supervision. The high school journal, 90(4), pp.44-54. 